\title{
Faktor Risiko Hipospadia pada Anak di RSUP Dr. Sardjito Yogyakarta
}

\author{
F. Jerry Tangkudung, S. Yudha Patria, Eggi Arguni \\ Bagian Ilmu Kesehatan Anak Fakultas Kedokteran Universitas Gadjah Mada RSUP Dr. Sardjito, Yogyakarta
}

Latar belakang. Dilaporkan peningkatan kejadian hipospadia dan faktor risiko, salah satunya adalah paparan pestisida. Faktor risiko lainnya adalah riwayat obstetri dan riwayat pada masa neonatus.

Tujuan. Mengetahui faktor risiko terjadinya hipospadia pada anak.

Metode. Penelitian kasus kontrol yang dilakukan sejak tahun 2008-2011 di rumah sakit Dr. Sardjito dengan menggunakan catatan rekam medis. Besar subjek penelitian 120 subjek. Data dianalisis dengan uji chi-square dan regresi logistik.

Hasil. Terdapat 120 anak yang diteliti, $60(50 \%)$ anak dengan hipospadia dan $60(50 \%)$ tanpa hipospadia. Anak yang lahir dari ibu dengan usia saat hamil lebih dari 35 tahun memiliki faktor risiko lebih tinggi dibandingkan dengan usia ibu kurang dari 35 tahun adjusted odds ratio (AOR: 4,17; IK95\%: 1,12-15,49), sedangkan lokasi tempat tinggal dekat dengan areal persawahan (OR: 1,93: IK95\%: 0,90-4,13), riwayat lahir prematur (OR: 2,13; IK95\%: 0,97-4,52); berat badan lahir rendah (OR: 3,14; IK95\% 0,94-10,5), hipertensi pada ibu selama kehamilan (OR: 2,47; IK95\%: 0,71-85) dan diet vegetarian selama kehamilan (OR: 1,00; IK95\%: 0,06-16,3).

Kesimpulan. Usia ibu lebih dari 35 tahun merupakan faktor risiko terjadinya hipospadia pada anak.

Sari Pediatri 2016;17(5):396-400.

Kata kunci: hipospadia, faktor risiko, anak

\section{Risk Factors of Hypospadias among Children in Dr. Sardjito General Hospital}

\author{
F. Jerry Tangkudung, S. Yudha Patria, Eggi Arguni
}

Background. It has been reported increased incidence of hypospadias. There are many risk factors for hypospadias, one of which is exposure to pesticides. Other risk factors are obstetric and neonatal period histories.

Objective. To determine the risk factors for hypospadias in children.

Method. We conducted a case-control study in Dr. Sardjito General Hospital using hospital medical records from 2008 through 2011. The research sample consisted of 120 subjects. The data were analyzed using chi-square and logistic regression.

Results. A total of 120 children were enrolled, of whom 50\% (60) had hypospadias and 50\% (60) had no hypospadias. Children with mother's age of more than 35 years had a greater risk for having hypospadia compared to those whose mother's age of less than 35 years (adjusted odds ratio 4.17 (CI 95\% 1.12 - 15.49; p=0.033). Low birth weight, maternal vegetarian diet during pregnancy, maternal hypertension during pregnancy and rice field environment had no association with the development of hypospadias. Conclusion. Mother age of more than 35 years old during pregnancy is a risk factor for the development of hypospadia in children. Sari Pediatri 2016;17(5):396-400.

Keywords: hypospadias, risk factors, children

Alamat korespondensi: Dr. Fanny Jerry. S Tangkudung. Bagian Ilmu Kesehatan Anak FK UGM/ SMF Kesehatan Anak/RSUP DR. Sardjito, jalan. Kesehatan No. 1, Yogyakarta 55284, Telp (0274) 561616, 587333 Psw.543. Hp. 081340528221. Email: jerrytangkudung@gmail.com 
$\mathrm{H}$

ipospadia merupakan kelainan bawaan pada anak laki-laki, posisi anatomi pembukaan saluran kemih di bagian ventral atau bagian anterior penis. Bentuk penis biasanya melengkung dan ukurannya lebih pendek daripada laki-laki normal. Kelainan ini, apabila tidak di koreksi, dapat mengakibatkan terganggunya fertilitas dikemudian hari. ${ }^{1}$

Di negara barat, prevalensi hipospadia 8 berbanding 1000 kelahiran hidup dan dilaporkan mengalami peningkatan di setiap tahunnya. ${ }^{2,3}$ Pada kebanyakan kasus, faktor penyebab terjadinya hipospadia belum dapat diketahui dengan pasti, meskipun telah diketahui bahwa perkembangan saluran kemih terjadi pada minggu 7 sampai 16 minggu usia kehamilan dan sangat dipengaruhi oleh kadar androgen. ${ }^{4}$

Beberapa penelitian melaporkan hubungan hipospadia dengan bayi berat lahir rendah (BBLR), bayi prematur, dan riwayat hipertensi pada ibu. ${ }^{5-7}$ Hal ini disebabkan fungsi plasenta yang terganggu mengakibatkan regulasi hormonal dan penyediaan nutrisi pada janin terganggu sehingga memengaruhi pembentukan saluran uretra. Beberapa literatur menyebutkan bahwa terdapat hubungan antara kejadian hipospadia dengan paparan lingkungan yang berhubungan dengan bahan kimiawi, yaitu pestisida, progestin, dan juga dari pola diet vegetarian yang secara tidak langsung memengaruhi proses pembentukan urogenetalia. Ibu yang sedang hamil dan menjalani diet vegetarian dikatakan memiliki faktor risiko terjadinya hipospadia sebanyak 4 kali lebih banyak bila dibandingkan dengan ibu yang tidak menjalani diet vegetarian. Hal ini disebabkan phytoestrogen yang diketahui sebagai reseptor modulator estrogen alamiah yang dapat memengaruhi perkembangan urogenatalia. ${ }^{8,9}$ Peneliti ingin mengetahui faktor apa saja yang dapat menjadi faktor risiko terjadinya hipospadia di Yogyakarta. Berdasarkan laporan penelitian sebelumnya, Baskin dkk ${ }^{4}$ dan Aschim dkk, ${ }^{6}$ faktor tersebut adalah prematuritas, BBLR, usia ibu saat kehamilan, hipertensi dalam kehamilan, paparan kimiawi lingkungan oleh pestisida dan diet vegetarian selama kehamilan.

Penelitian kami lakukan untuk mengetahui pengaruh prematuritas, BBLR, usia ibu saat kehamilan, hipertensi dalam kehamilan, paparan kimiawi lingkungan oleh pestisida dan diit vegetarian selama kehamilan, sebagai faktor yang memengaruhi kejadian hipospadia.

\section{Metode}

Penelitian ini menggunakan rancang bangun kasus kontrol. Definisi kasus adalah pasien yang dirawat di RS. Sardjito dengan hipospadia. Kriteria inklusi adalah anak laki-laki usia 0 sampai dengan 18 tahun. Kriteria eksklusi adalah anak dengan kelainan bawaan lain. Besar sampel 120 subjek. Setelah ditetapkan kelompok anak dengan hipospadia dan kelompok anak tanpa hipospadia sesuai dengan definisi kasus dan kontrol, ditelusuri secara retrospektif terhadap adanya pajanan oleh faktor risiko (usia ibu saat hamil, lokasi tempat tinggal dekat dengan areal persawahan, BBLR, prematuritas, hipertensi saat kehamilan dan diet vegetarian selama kehamilan).

Penelitian ini dilaksanakan di Instalasi Kesehatan Anak RS Dr. Sardjito Yogyakarta dimulai dari Januari 2008 sampai dengan 31 Desember 2013. Populasi target adalah anak yang menderita hipospadia. Populasi terjangkau adalah anak yang menderita hipospadia dan tercatat di rekam medik dengan kode ICD-X Q.54.

Pengambilan sampel yang digunakan adalah consecutive sampling. Dilakukan matching pada kelompok kontrol secara berpasangan dengan memperhatikan usia yang tercatat pada rekam medis. Variabel yang ada dalam penelitian dianalisis secara deskriptif, kemudian dilakukan analisis univariat menggunakan chi square. Selanjutnya, dilakukan analisis multivariat regresi logistik.

Luaran penelitian ini adalah mengetahui apakah usia ibu saat hamil, lokasi tempat tinggal dekat dengan areal persawahan, BBLR, prematuritas, hipertensi saat kehamilan dan diet vegetarian selama kehamilan merupakan faktor risiko terjadinya hipospadia pada anak.

\section{Hasil}

Terdapat 120 subjek, terdiri atas 60 anak dengan hipospadia dan 60 anak yang tidak hipospadia. Subjek merupakan anak laki-laki dengan usia 0-18 tahun (Tabel 1). Analisis univariat berdasarkan faktor risiko yang memengaruhi kejadian hipospadia antar variabel $\mathrm{p}<0,05$ memberikan arti bahwa terdapat hubungan yang bermakna antara faktor risiko dengan kejadian hipospadia (Tabel 2).

Hasil analisis multivariat menunjukkan bahwa faktor risiko yang berhubungan dengan hipospadia 
adalah usia ibu saat kehamilan (AOR: 4,17; IK95\%: 1,1-15,4). Usia ibu saat hamil di atas 35 tahun akan meningkatkan risiko terjadinya hipospadia 4,17 kali lebih besar bila dibandingkan dengan usia ibu kurang dari 35 tahun saat hamil.

\section{Pembahasan}

Hubungan kejadian hipospadia dengan BBLR dan prematuritas, dari analisis univariat BBLR dan prematuritas, memberikan pengaruh terhadap kejadian

Tabel 1. Karakteristik dasar subjek penelitian

\begin{tabular}{lcc}
\hline Variabel & Kasus $(\mathrm{n}=60)$ & Kontrol $(\mathrm{n}=60)$ \\
\hline Tipe hipospadia, $\mathrm{n}(\%)$ & & \\
$\quad$ Anterior & $16(26,7)$ & - \\
$\quad$ Middle & $7(11,7)$ & - \\
$\quad$ Posterior & $37(61,7)$ & - \\
Diit vegetarian selama kehamilan & & \\
$\quad$ Ya & $1(1,7)$ & $1(1,7)$ \\
$\quad$ Tidak & $59(98,3)$ & $59(98,3)$ \\
BBLR, (gram), n (\%) & & \\
$\quad<2500$ & $11(18,3)$ & $3(5)$ \\
$\quad \geq 2500$ & $49(81,7)$ & $57(95)$ \\
Usia kehamilan, (minggu), n (\%) & & \\
$\quad<37$ & $26(43)$ & $16(26)$ \\
$\quad>37$ & $34(57)$ & $44(74)$ \\
Usia ibu pada saat hamil, (tahun), n (\%) & & $4(7)$ \\
$\quad>35$ & $11(18,3)$ & $56(93)$ \\
$\quad<35$ & $49(81,7)$ & \\
Hipertensi kehamilan, $\mathrm{n}(\%)$ & & $4(15)$ \\
$\quad$ Ya & $51(85)$ & $56(93)$ \\
$\quad$ Tidak & & \\
Lokasi tempat tinggal dekat dengan areal persawahan (feet) & $43(72)$ & $34(56)$ \\
$\quad<2600$ & $17(28)$ & $26(44)$ \\
$\quad>2600$ &
\end{tabular}

Tabel 2. Hasil analisis univariat hubungan antara faktor risiko

\begin{tabular}{lcc}
\hline Variabel & OR (IK95\%) & $\mathrm{p}$ \\
\hline BBLR & $3,14(0,940-10,507)$ & 0,053 \\
Prematuritas & $2,10(0,977-4,528)$ & 0,056 \\
Diet vegetarian & $1,00(0,06-16,366)$ & 1,000 \\
Lokasi tempat tinggal dekat area persawahan & $1,93(0,906-4,132)$ & 0,087 \\
Usia ibu risiko tinggi & $3,14(0,940-10,507)$ & 0,053 \\
Hipertensi pada ibu selama kehamilan & $2,47(0,717-8,515)$ & 0,142 \\
\hline
\end{tabular}

Tabel 3. Hasil analisis multivariat dan regresi logistik hubungan antara faktor risiko

\begin{tabular}{lcc}
\hline Variabel & Adjusted odds ratio $($ AOR $)$ IK 95\% & $\mathrm{p}$ \\
\hline BBLR & $2,92(0,78-10,815)$ & 0,108 \\
Prematuritas & $2,04(0,871-4,799)$ & 0,100 \\
Diet vegetarian & - & - \\
Lokasi tempat tinggal dekat area persawahan & $2,27(0,977-4,985)$ & 0,057 \\
Usia ibu risiko tinggi & $4,17(1,123-15,497)$ & 0,033 \\
Hipertensi pada ibu selama kehamilan & $0,88(0,208-3,720)$ & 0,862 \\
\hline
\end{tabular}


hipospadia. Bayi dengan berat badan lahir rendah dapat menjadi penanda bahwa telah terjadi hambatan pertumbuhan janin karena plasenta ibu kurang dalam memberikan nutrisi dan berkurangnya pula produksi hCG sehingga memengaruhi sintesis androgen.

Usia ibu saat hamil memiliki keterkaitan kejadian dengan hipospadia, usia ibu di atas 35 tahun cenderung akan mengakibatkan hipospadia 4,17 kali lebih tinggi. Penelitian kami sejalan dengan Carmichael $\mathrm{dkk}^{8}$ yang melaporkan seorang ibu yang hamil pada usia di atas 35 tahun memiliki risiko aliran darah plasenta yang tidak baik dikarenakan kekakuan pembuluh darah. Dengan demikian, asupan nutrisi ke janin terganggu sehingga mengakibatkan hambatan pertumbuhan dan proses metabolisme janin.

Diet vegetarian yang dilakukan selama masa kehamilan, menunjukkan hasil statistik yang tidak berhubungan dengan kejadian hipospadia. Sementara itu, North ${ }^{9}$ melaporkan bahwa pada ibu hamil yang hanya mengonsumsi sayuran hijau saja atau sedang menjalani pola makan vegetarian, dapat terjadi penurunan vitamin B 12, choline, methionine yang akan memengaruhi sintesis estrogen dengan pembentukan efek phytoestrogen. North mendapatkan bahwa diet vegetarian memberikan pengaruh terhadap kejadian hipospadia 4,6 kali lipat dibandingkan dengan ibu hamil yang menjalani diet normal.

Tidak didapatkan hubungan antara kejadian hipospadia dengan paparan pestisida terhadap lingkungan sekitar yang dikatakan sebagai faktor risiko meningkatnya kejadian hipospadia. Kelemahan dari penelitian kami adalah terdapat keterbatasan dalam menilai berapa lama paparan pestisida telah berlangsung. Selain itu, kami tidak meneliti jenis pestisida yang digunakan. Beberapa jenis pestisida, antara lain insektisida, fungisida, dan herbisida, diketahui dapat memberikan pengaruh pada perkembangan hormon endokrin. Hal tersebut diakibatkan oleh sifat pestisida yang anti androgenik. Meyer ${ }^{10}$ melaporkan hanya jenis tertentu dari pestisida yang dapat meningkatkan risiko terjadinya hipospadia, yaitu diclofop-methyl yang termasuk dalam pestisida jenis herbisida. Dikatakan, secara statistik, selain jenis herbisida ini tidak didapatkan hasil yang bermakna bahwa pestisida meningkatkan risiko terjadinya hipospadia. Garry $\mathrm{dkk}^{11}$ melaporkan peningkatan terjadinya kelainan perkembangan genitalia yang diturunkan akibat pestisida. Pada penelitian lain melaporkan paparan pestisida dalam radius 2600 feet atau 780 meter dapat menyebabkan cedera ditingkat sel. Apabila ibu hamil terpapar pestisida dalam kurun waktu 3 bulan terutama rentang usia kehamilan 6 sampai 16 minggu maka perkembangan janin dapat terpengaruh sampai kepada timbulnya penyakit keganasan.. ${ }^{10,12}$

Kelebihan penelitian kami adalah setelah dilakukan pencarian dari literatur jurnal $P U B M E D$, penelitian ini yang pertama kali menggunakan perasat Google Earth dalam melihat lokasi tempat tinggal dekat dengan areal persawahan.

\section{Kesimpulan}

Hasil penelitian kami menyimpulkan bahwa faktor risiko yang terbukti berhubungan secara statistik dengan kejadian hipospadia adalah usia ibu disaat kehamilan, sedangkan tempat tinggal dekat dengan areal persawahan, prematuritas, berat badan lahir yang rendah, diet vegetarian, dan hipertensi pada kehamilan tidak mempunyai nilai kemaknaan dengan kejadian hipospadia. Di Indonesia, perlu dilakukan penelitian lebih lanjut dengan desain penelitian prospektif, untuk mengetahui penyebab dan faktor risiko yang dapat mempengaruhi kejadian hipospadia.

\section{Daftar pustaka}

1. Hanh T. Hypospadia: Gene mapping and candidate gene studies. Sweden: Karolinska Instutet;2009.

2. Czeizel A, Toth J, Erodi E. Aetiological studies of hypospadias in Hungary. Hum Hered 1979;29:16671.

3. Pierik FH, Burdorf A, Deddens JA. Maternal and paternal risk factors for cryptorchidism and hypospadias: a case-control study in newborn boys. Environ Health Perspect 2004;112:1570-6.

4. Baskin LS, Himes K, Colborn T. Hypospadias and endocrine disruption: is there a connection? Environ Health Perspect 2001;109:1175-6.

5. Akre O, Boyd HA, Melbye M. Maternal and gestational risk factors for hypospadias. Environ Health Perspect 2008;116:1071-6.

6. Aschim EL, Haugen TB, Grotmol T. Risk factors for hypospadias in Norwegian boys - association with testicular dysgenesis syndrome. Int J Androl 2004;27:213-21.

7. Boisen KA, Chellakooty M, Main KM. Hypospadias 
in a cohort of 1072 Danish newborn boys: prevalence and relationship to placental weight, anthropometrical measurements at birth, and reproductive hormone levels at three months of age. J Clin Endocrinol Metab 2005;90:4041-6.

8. Carmichael SL, Shaw GM, Curry CJ. Hypospadias in California: trends and descriptive epidemiology. Epidemiology 2003;14:701-6.

9. North K, Golding JA. Maternal vegetarian diet in pregnancy is associated with hypospadias. The ALSPAC Study Team. Avon Longitudinal Study of Pregnancy and Childhood. BJU Int 2015;85:1589-95.
10. Meyer KJ, Eif JS, Nuckols JR. pesticide use and hypospadias in eastern Arkansas. Environ Health Perspect 2006;114:1589-95.

11. Garry VF, Harkins ME, Burroughs BL. Birth defects, season of conception, and sex of children born to pesticide applicators living in the Red River Valley of Minnesota, USA. Environ Health Perspect 2002;110:1289-96.

12. Aschengrau A, Ozonoff D, Coogan P. Cancer risk and residential proximity to cranberry cultivation in Massachusetts Increased birth prevalence of isolated hypospadias in Hungary. Am J Public Health 1996;86:1289-96. 